\title{
Genetic diversity for physiological quality of seeds from corn (Zea mays L.) intervarietal crossbreeds ${ }^{1}$
}

\author{
Daniele Nerling 2 , Cileide Maria Medeiros Coelho ${ }^{3 *}$, Rubens Onofre Nodari ${ }^{2}$
}

\begin{abstract}
The physiological quality is based on the genotype and may be accompanied since the first stages of selection through the study of genetic diversity. The purpose of this study was to evaluate the parental genetic contribution in the seed physiological quality in corn intervarietal crossbreeds. The intervarietal crossbreeds were performed using landraces genotypes, open pollinated varieties and commercial hybrids. The seeds obtained from the crossbreed, their equivalents and parentals were evaluated regarding their water percentage, germination, germination speed rate, accelerated aging, field emergence and electrical conductivity. The seeds obtained in the crossbreed are viable and vivid with heterosis when compared with the parentals. The accelerated aging test was more effective for selecting the strongest genotypes. The canonical variables were useful to group the genotypes that presented similar physiological characteristics. The genotypes MPA $01 \times$ Pixurum 05 , MPA 01 x AS1565, MPA 01 x SJC5886, SJC5886 x Pixurum 05 and Fundacep 35 x SCS 154 Fortuna were the best crossbreeds regarding the production of better physiological quality seeds.
\end{abstract}

Index terms: heterosis, viability, vigor, dissimilarity.

\section{Diversidade genética para qualidade fisiológica de sementes produzidas por cruzamentos intervarietais de milho (Zea mays L.)}

\begin{abstract}
RESUMO - A qualidade fisiológica tem sua base no genótipo e pode ser monitorada desde as primeiras etapas de seleção pelo estudo da divergência genética. O objetivo deste trabalho foi avaliar a contribuição genética dos parentais na qualidade fisiológica de sementes obtidas em cruzamentos intervarietais de milho. Foram realizados cruzamentos intervarietais utilizando genótipos crioulos, variedades de polinização aberta e híbridos comerciais. As sementes obtidas nos cruzamentos bem como seus recíprocos e genitores foram avaliadas quanto ao teor de água, germinação, índice de velocidade de germinação, envelhecimento acelerado, emergência em campo e condutividade elétrica. As sementes obtidas nos cruzamentos são viáveis e vigorosas apresentando heterose em relação aos parentais. O envelhecimento acelerado foi o teste mais eficiente para selecionar os genótipos quanto ao nível de vigor. As variáveis canônicas foram eficientes em agrupar os genótipos com qualidade fisiológica semelhante. Os genótipos MPA 01 x Pixurum 05, MPA 01 x AS1565, MPA 01 x SJC 5886, SJC 5886 x Pixurum 05 e o genótipo Fundacep 35 x SCS 154 Fortuna, foram os melhores cruzamentos para a produção de sementes de melhor qualidade fisiológica.
\end{abstract}

Termos para indexação: heterose, viabilidade, vigor, dissimilaridade.

\section{Introduction}

The competitiveness in the seed sector has led the producing companies to invest and adopt higher quality standards for seeds. The main effect expected regarding the genetic improvement is a productivity increase (Gomes et al., 2000); however, the heterosis basis for the seeds quality is also an important factor. The seeds quality may be defined as the sum of genetic, physical, physiologic and sanitary attributes that affect the seed capacity

${ }^{1}$ Submitted on 02/14/2013. Accepted for publishing on 05/22/2013. ${ }^{2}$ Departamento de Fitotecnia, Universidade Federal de Santa Catarina, Caixa Postal 476, 88034-001 - Florianópolis, SC, Brasil. to perform vital functions, being related to germination, vigor and longevity (Moterle et al., 2011). The contribution of genetic attributes to the seeds quality requires further studies.

The physiological quality is based on the genotype, and may be accompanied from the first stages of selection, obtained with tests of viability and vigor during the genetic improvement process (Marcos-Filho, 1999). Despite the obvious effect of the environment over the seeds quality, the maximum quality potential, such as seedling germination,

${ }^{3}$ Universidade Estadual de Santa Catarina, UDESC/CAV, Caixa Postal 281, 88520-000 - Lages, SC, Brasil.

*Corresponding author<cileidecoelho@yahoo.com.br; cileide.coelho@pq.cnpq.br> 
emergence and vigor, is genetically controlled (Prete and Guerra, 1999) and may be handled exploring the genetic variance of a species or lineages in the crossbreeding process (Gondim et al., 2006).

The few reports about the genetic effects related to the seeds quality show that it is possible to obtain genetic gain. According to Gomes et al. (2000), the germination and vigor results indicated the hybrids are superior to the lineages regarding the physiological quality. Reis et al. (2011), in a research with 14 sweet corn genotypes, observed the effects of heterosis in the seeds quality, that is, the hybrid seeds presented heterosis variation from $4,39 \%$ to $15,62 \%$ for the germination percentage and a heterosis variation from $-27,5 \%$ to $16,67 \%$ for the vigor comparing with the parental. Despite this variation, it is possible to obtain high vigor seeds and a better performance for the seedling emergence consistency under field conditions (Pereira et al., 2008). Mertz et al. (2009) state that the physiological quality characteristics of soy seeds are genetically inherited from its parentals, thus, different varieties of one species may present variation of vigor, germination and field emergence.

The seeds quality may be verified in advance, based on the genetic difference between the parentals, which may be foreseen based on agronomic, morphologic, nutritional quality, physiologic and molecular characteristics. The dissimilarity among such characteristics is measured by multivariate analysis techniques, which enables to express the genetic diversity degree between the parentals analyzed (Cruz et al., 2004).

Due to the fact there are few researches that evaluate the genetic contribution in the physiological quality of corn seeds, and due to the great genetic diversity observed in landrace and open pollination varieties, the purpose of this study was to evaluate the genetic contribution of parentals in the physiological quality of seeds obtained by intervarietal crossbreed between landrace genotypes, open pollination varieties and corn hybrids.

\section{Material and Methods}

The seeds production field was settled on an experimental unit experiment from Oestebio Cooperative in São Miguel do Oeste/SC and the physiological analyses were held in the Laboratory of Seed Testing at University of Santa Catarina. The 28 processes evaluated were composed by: 8 parentals: a simple conventional hybrid (AS 1565), four varieties of open pollination (SCS 155 Catarina, SCS 154 Fortuna, Fundacep 35 and BRS 4150) and three landraces varieties (Pixurum 05, MPA 01 and SJC 5886), 10 intervarietal and their equivalents (Table 1). A forced pollination was executed; the pollen collection and fertilization were made on the same day; for the pest control, chemical methods such as desiccants were used. For the planting, organic fertilizing was used and nitrogen was applied in accordance with the recommendation for each species.

Table 1. Intervarietais corn crossbreeds and their equivalents to establish the genetic contribution for the physiological quality of the seeds.

\begin{tabular}{cl}
\hline Treatment & \multicolumn{1}{c}{ Genotype* } \\
\hline 1 & Pixurum 05 \\
2 & MPA 01 \\
3 & SCS 155 Catarina \\
4 & SCS 154 Fortuna \\
5 & Fundacep 35 \\
6 & AS 1565 \\
7 & SJC 5886 \\
8 & BRS 4150 \\
9 & MPA 01 x Pixurum 05 \\
10 & Pixurum 05 x MPA 01 \\
11 & MPA 01 x AS 1565 \\
12 & AS 1565 x MPA 01 \\
13 & MPA 01 x SJC 5886 \\
14 & SJC 5886 x MPA 01 \\
15 & Pixurum 05 x SCS 155 Catarina \\
16 & SCS 155 Catarina x Pixurum 05 \\
17 & Pixurum 05 x AS 1565 \\
18 & AS 1565 x Pixurum 05 \\
19 & Pixurum 05 x SC 5886 \\
20 & SJC 5886 x Pixurum 05 \\
21 & Pixurum 05 x BRS 4150 \\
22 & BRS 4150 x Pixurum 05 \\
23 & Fundacep 35 x SCS 154 Fortuna \\
24 & SCS 154 Fortuna x Fundacep 35 \\
25 & Fundacep 35 x AS 1565 \\
26 & AS 1565 x Fundacep 35 \\
27 & AS 1565 XCS 154 Fortuna \\
28 & SCS 154 Fortuna x AS 1565 \\
\hline & \\
\hline
\end{tabular}

*The name that comes first in the crossbreeds is the genotype used as female parental.

The samples used to evaluate the physiological quality of the first generation seeds (F1) in relation to their parentals have been obtained at the point of harvest. The corn-cobs were manually husked; the seeds were dried in the shade until they reached a moisture level of approximately $13 \%$. A representative sample of seeds (about $1 \mathrm{~kg}$ ) from each parental and from the first generation (F1) was reduced in the laboratory in order to obtain the working sample. The working sample was obtained by the passage of seeds through a Gamet type homogenizer in order to get four replications of approximately $250 \mathrm{~g}$. These four replications were used to perform all the 
physiological quality tests (Coelho et al., 2010), except for the seed moisture content, performed with two replications, in accordance with the Rules for Seed Testing (Brasil, 2009). After that, the samples were stored in a dry chamber $\left(8^{\circ} \mathrm{C} ; 50 \%\right.$ relative humidity) until the moment of analysis.

Germination: eight replications of 50 seeds were placed on germitest paper that was previously dampened with distilled water. After the sowing, the paper rolls were put in a germinator at $25^{\circ} \mathrm{C}$. The first counting was done on the fifth day and the final counting was after seven days (Brasil, 2009), establishing normal seedlings percentage.

Germination Speed Rate: the germinated seeds were counted daily starting on the fourth day after the sowing, considering the normal seedlings. Afterwards, the germination speed index was established with the expression proposed by (Edmond and Drapala, 1958):

$$
\mathrm{GS}=\frac{((\mathrm{N} 1 \times \mathrm{G} 1)+(\mathrm{N} 2 \times \mathrm{G} 2)+\ldots+(\mathrm{Nn} \times \mathrm{Gn}))}{(\mathrm{G} 1+\mathrm{G} 2+\ldots+\mathrm{Gn})}
$$

Where: GS: number of days for the germination; N1: number of days for the first evaluation; G1: number of germinated seeds in the first evaluation; Nn: number of days remaining for the last evaluation; Gn: number of germinated seeds in the last evaluation.

Electrical Conductivity: replications of 50 seeds, with known weight, were placed on $75 \mathrm{~mL}$ plastic cups filled with distilled water and taken to the germinator at $25{ }^{\circ} \mathrm{C}$. The electrical conductivity readings were taken after 10 hours by a portable conductivity meter, model MB-11P-Marte. The conductivity value in $\mu \mathrm{S} . \mathrm{cm}^{-1}$ was divided by the initial weight of seeds obtained at each replication and the average values were calculated and expressed in $\mu \mathrm{S} . \mathrm{cm}^{-1} \cdot \mathrm{g}^{-1}$ of seed (Vieira and Carvalho, 1994).

Field Emergence: this test was conducted in São Miguel do Oeste/SC. The experimental design was made in randomized blocks, adding up to 28 treatments, with four replications of 50 seeds. The seeds were sowed in $4 \mathrm{~m}$ long furrows, with approximately $2 \mathrm{~m}$ of depth and the space between furrows was $0.4 \mathrm{~m}$. The seedling counting took place 14 days after the sowing, having the results expressed in percentage (Nakagawa, 1994).

Accelerated Aging: the seeds were places on stainless steel Screen, in 'gerbox' with $40 \mathrm{~mL}$ of distilled water. The boxes were kept in B.O.D. at $45^{\circ} \mathrm{C}$ for $72 \mathrm{~h}$ (Marcos-Filho, 2005) and, after this aging period, the seeds were put to germinate, and the normal seedlings were evaluated five days after the sowing, according to Brasil (2009).

The heterosis estimates (\%), comparing each crossbreed with the parentals average, was calculated by the expression:
Heterosis $(\%)=\underline{\text { Hybrid average }- \text { Parentals average } \mathrm{x} 100}$ Parentals average

The results obtained as percentage values were converted to sine arc $\sqrt{ } \%$ and later, a variance analysis and a Scott Knott test were made to separate the averages and establish a comparison between the parentals and crossbreed combinations. The genetic diversity was estimated by the general distance of Mahalanobis $\left(\mathrm{D}^{2}\right)$, after that, the grouping analyses were performed, having the Singh method (1981) and the canonical variables as criteria, respectively, represented in scatter plot. The data were analyzed by the Genes program (Cruz, 2006).

\section{Results and Discussion}

There was a relevant difference for all the variables analyzed. The germination percentage for genotypes and crossbreeding was, at least, $90 \%$. Among the parentals, four genotypes presented $98 \%$ of germination: 1, 2, 6 e 8, being superior to the others. The highest percentage was found in the seeds that resulted from crossbreed 19 (99\%) (Table 2).

The heterosis regarding the parentals average, for the germination test, ranged from $-8,16 \%$ (crossbreed 9) to $5,32 \%$ (crossbreed 19). This result, as well as other studies, shows there is heterosis for germination. Gomes et al. (2000), when working with corn, obtained heterosis estimated that vary from $-6,3 \%$ a $8,4 \%$. However, it is different from results obtained by Reis et al. (2011), who observed a higher heterosis in the evaluation of 14 sweet corn genotypes, with variation of $4,39 \%$ and $15,62 \%$. The results presented in this study indicate the possibility of obtaining hybrid seeds with excellent physiological quality.

Despite the heterosis estimate for crossbreed 13 being negative $(-2,13 \%)$, for the respective equivalent, the heterosis estimate was positive $(2,13 \%)$. The equivalent effect must also be considered, and it was noted on crossbreed 17 and crossbreed 25 (Table 2). These results suggest that choosing between female and male parentals is extremely important for obtaining viable seeds. These results confirm the other studies that evaluated the role of heterosis on the seeds quality and observed the effect of equivalent crossbreed. Gomes et al. (2000) evaluated the effect of heterosis in the seeds quality of 30 corn crossbreeds and observed the effect in 6 equivalent crossbreeds evaluated; the parentals of the crossbreeds were chosen to produce the hybrid corn seeds, in order to obtain high germination potential seeds.

In the field emergence test, the genotypes used as parentals presented variation in the emergence percentage between $88 \%$ and $97 \%$. Among the crossbreeds, the emergence percentage ranged from $82 \%$ to $96 \%$, however, there was no relevant 
difference between the crossbreeds. When comparing the field emergence test and the laboratory emergence, it is possible to note that 15 genotypes $(4,9,12,13,15,17,18,19,21,22$,
23, 24, 26, 27 and 28) presented similar behavior in both tests (Table 2). This result shows the influence of genotypes in the seeds vigor (Marcos-Filho, 1999).

Table 2. Germination percentage (GERM), heterosis (H), field emergence percentage (EMC) and germination speed index (GS) of the parentals, their crossbreeds and equivalents.

\begin{tabular}{|c|c|c|c|c|}
\hline \multirow{2}{*}{ Treatments } & \multicolumn{2}{|c|}{ GERM } & \multirow{2}{*}{$\begin{array}{c}\text { EMC } \\
(\%)\end{array}$} & \multirow{2}{*}{$\begin{array}{c}\text { GS } \\
\text { Days }\end{array}$} \\
\hline & Mean $(\%)$ & H (\%) & & \\
\hline 1 Pixurum 05 & $98 \mathrm{~b}$ & - & $88 \mathrm{a}$ & $3.53 \mathrm{~d}$ \\
\hline 2 MPA 01 & $98 \mathrm{~b}$ & - & $94 \mathrm{a}$ & $3.76 \mathrm{c}$ \\
\hline 3 SCS 155 Catarina & $90 \mathrm{f}$ & - & $94 \mathrm{a}$ & $4.07 \mathrm{~b}$ \\
\hline 4 SCS 154 Fortuna & $96 \mathrm{c}$ & - & $97 \mathrm{a}$ & $3.69 \mathrm{c}$ \\
\hline 5 Fundacep 35 & $96 \mathrm{c}$ & - & $91 \mathrm{a}$ & $4.12 \mathrm{~b}$ \\
\hline 6 AS 1565 & $98 \mathrm{~b}$ & - & $92 \mathrm{a}$ & $3.69 \mathrm{c}$ \\
\hline 7 SJC 5886 & $90 \mathrm{f}$ & - & $95 \mathrm{a}$ & $3.78 \mathrm{c}$ \\
\hline 8 BRS 4150 & $98 \mathrm{~b}$ & - & $89 \mathrm{a}$ & $3.83 \mathrm{c}$ \\
\hline 9 MPA $01 \times$ Pixurum 05 & $90 \mathrm{f}$ & -8.16 & $91 \mathrm{a}$ & $3.61 \mathrm{~d}$ \\
\hline 10 Pixurum 05 x MPA 01 & $94 \mathrm{~d}$ & -4.08 & $85 \mathrm{a}$ & $3.56 \mathrm{~d}$ \\
\hline 11 MPA 01 x AS 1565 & $94 \mathrm{~d}$ & -4.59 & $87 \mathrm{a}$ & $4.08 \mathrm{~b}$ \\
\hline 12 AS 1565 x MPA 01 & $94 \mathrm{~d}$ & -4.59 & $89 \mathrm{a}$ & $3.44 \mathrm{~d}$ \\
\hline 13 MPA 01 x SJC 5886 & $92 \mathrm{e}$ & -2.13 & $89 \mathrm{a}$ & $3.88 \mathrm{c}$ \\
\hline 14 SJC $5886 \times$ MPA 01 & $96 \mathrm{c}$ & 2.13 & $88 \mathrm{a}$ & $3.71 \mathrm{c}$ \\
\hline 15 Pixurum 05 x SCS 155 Catarina & $98 \mathrm{~b}$ & 4.26 & $94 \mathrm{a}$ & $3.66 \mathrm{c}$ \\
\hline 16 SCS 155 Catarina x Pixurum 05 & $92 \mathrm{e}$ & -2.13 & $85 \mathrm{a}$ & $3.87 \mathrm{c}$ \\
\hline 17 Pixurum 05 x AS 1565 & $94 \mathrm{~d}$ & -4.08 & $93 \mathrm{a}$ & $3.52 \mathrm{~d}$ \\
\hline 18 AS 1565 x Pixurum 05 & $96 \mathrm{c}$ & 2.13 & $84 \mathrm{a}$ & $3.33 \mathrm{~d}$ \\
\hline 19 Pixurum 05 x SJC 5886 & 99 a & 5.32 & $90 \mathrm{a}$ & $4.12 \mathrm{~b}$ \\
\hline 20 SJC 5886 x Pixurum 05 & $92 \mathrm{e}$ & -2.13 & $91 \mathrm{a}$ & $4.19 \mathrm{~b}$ \\
\hline 21 Pixurum 05 x BRS 4150 & $94 \mathrm{~d}$ & -4.08 & $92 \mathrm{a}$ & $4.15 \mathrm{~b}$ \\
\hline 22 BRS 4150 x Pixurum 05 & $94 \mathrm{~d}$ & -4.08 & $91 \mathrm{a}$ & $3.97 \mathrm{~b}$ \\
\hline 23 Fundacep 35 x SCS 154 Fortuna & $90 \mathrm{f}$ & -6.25 & $82 \mathrm{a}$ & $4.37 \mathrm{a}$ \\
\hline 24 SCS 154 Fortuna x Fundacep 35 & $96 \mathrm{c}$ & 0.00 & $94 \mathrm{a}$ & $4.24 \mathrm{a}$ \\
\hline 25 Fundacep 35 x AS 1545 & $96 \mathrm{c}$ & -1.03 & $90 \mathrm{a}$ & $4.30 \mathrm{a}$ \\
\hline 26 AS 1565 x Fundacep 35 & $98 \mathrm{~b}$ & 1.61 & $91 \mathrm{a}$ & $4.17 \mathrm{~b}$ \\
\hline 27 AS 1565 x SCS 154 Fortuna & $96 \mathrm{c}$ & -1.03 & $96 \mathrm{a}$ & $4.02 \mathrm{~b}$ \\
\hline 28 SCS 154 Fortuna x AS 1565 & $92 \mathrm{e}$ & -5.15 & $92 \mathrm{a}$ & $4.09 \mathrm{~b}$ \\
\hline
\end{tabular}

Means followed by the same letter in the column do not differ inwardly by the Scott \& Knott test, at $5 \%$.

The genotypes 3 and 7, which presented higher field emergence percentage in relation with the laboratory germination, evidenced that the genetic diversity is an advantage in the unfavorable conditions of the field environment.

Regarding the germination speed index, there was no relevant difference among the genotypes (GS 3,8 to 3,9 days). Thus, the GS was not used as a discriminating parameter in the genotypes selection, but it was considered a determining factor for establishing the field cultivation.

For the electrical conductivity it was possible to observe that the parentals MPA 01 and SJC 5886 presented the lower values, 3,12 $\mu \mathrm{S} . \mathrm{cm}^{-1} \cdot \mathrm{g}^{-1}$ e $3,26 \mu \mathrm{S} . \mathrm{cm}^{-1} \cdot \mathrm{g}^{-1}$, respectively. Among the crossbreeds, four genotypes (9, 10, 15 and
20) presented lower values of electrical conductivity. The frequent occurrence of leachate may be related with the climate condition during the seeds development. During the maturation period, the seeds were exposed to very little rain, which may have affected the transfer of dry matter to the seeds and compromised the integrity of the cell membranes and the deposition of reserves (Ávila and Albrecht, 2010). However, it was possible to note the four crossbreeds $(9,10,15$ and 20) that provided greater integrity for the cell membranes were composed by landrace genotypes.

The heterosis estimates for electrical conductivity range from $-28,84 \%$ to $+55,70 \%$. The seeds obtained by the crossbreeds were expected to present negative heterosis due to 
the fact they were more vivid, however, ten genotypes $(11,12$, $13,14,16,18,19,23,24$ and 26) presented positive estimates, indicating that the crossbreeds had a poorer performance when compared with their parentals.

On the accelerated aging test, relevant differences of vigor among the parentals, crossbreeds and equivalents were observed. The parentals 5 and 7 presented higher germination values, $91 \%$ and $90 \%$, respectively. Among the crossbreeds, number 20 presented $95 \%$ of germination on this test. The parental that showed to be less tolerant to this test was hybrid AS 1565 and among the crossbreeds, it was number 26, both with $79 \%$ of germination.

According to the results, 14 genotypes $(5,7,9,10,11,13$, $14,15,17,20,22,23,24$ and 27) presented seeds with more than $90 \%$ of germination on the test, indicating that these seeds are more vigorous and that the genotypes are more likely to endure the storage. These results confirm the percentages obtained by Miranda et al. (2003), whose values range from $62 \%$ to $98 \%$ in different populations of landrace corn, and by Gomes et al. (2000), who obtained percentages from $78 \%$ to $98 \%$ in corn crossbreeds. However, in commercial hybrid varieties, the percentage ranged from $81 \%$ to $47 \%$ (Bittencourt et al., 2012). Such results suggest the genotype may have some influence on the tolerance to stress caused by the accelerated aging.

The heterosis variation range, for the accelerated aging test, was from $-7,22 \%$ to $+12,39 \%$. It was possible to observe the germination of crossbreed seeds, within the test conditions, was higher than their parental, indicating heterosis effect (Table 3). The heterosis effect for accelerated aging was also observed by Gomes et al. (2000), indicating that the crossbreed seeds are more vigorous and, consequently, are more resistant to storage than their parentals.

Table 3. Electrical conductivity (EC) and Accelerated aging (AA) of the parentals, their crossbreeds and equivalents, and estimate means of heterosis $(\mathrm{H})$ for the genotypes.

\begin{tabular}{|c|c|c|c|c|}
\hline \multirow[b]{2}{*}{ Treatment } & \multicolumn{2}{|c|}{$\mathrm{EC}$} & \multicolumn{2}{|c|}{ AA } \\
\hline & $\begin{array}{c}\text { Means } \\
\mu \mathrm{S} . \mathrm{cm}^{-1} \cdot \mathrm{g}^{-1}\end{array}$ & $\mathrm{H}(\%)$ & Means (\%) & $\mathrm{H}(\%)$ \\
\hline 1 Pixurum 05 & $4.553 \mathrm{c}$ & - & $85 \mathrm{~b}$ & - \\
\hline 2 MPA 01 & $3.059 \mathrm{a}$ & - & $87 \mathrm{~b}$ & - \\
\hline 3 SCS 155 Catarina & $3.656 \mathrm{~b}$ & - & $85 \mathrm{~b}$ & - \\
\hline 4 SCS 154 Fortuna & $4.347 \mathrm{c}$ & - & $86 \mathrm{~b}$ & - \\
\hline 5 Fundacep 35 & $4.580 \mathrm{c}$ & - & $91 \mathrm{a}$ & - \\
\hline 6 AS1565 & $4.749 \mathrm{c}$ & - & $79 \mathrm{c}$ & - \\
\hline 7 SJC5886 & $3.215 \mathrm{a}$ & - & $90 \mathrm{a}$ & - \\
\hline 8 BRS4150 & $4.654 \mathrm{c}$ & - & $88 \mathrm{~b}$ & - \\
\hline 9 MPA $01 \times$ Pixurum 05 & $2.708 \mathrm{a}$ & -28.84 & $94 \mathrm{a}$ & 9.30 \\
\hline 10 Pixurum 05 x MPA 01 & $2.963 \mathrm{a}$ & -22.15 & $91 \mathrm{a}$ & 5.52 \\
\hline 11 MPA $01 \times$ AS 1565 & $4.568 \mathrm{c}$ & 17.00 & 93 a & 12.39 \\
\hline 12 AS1565 x MPA 01 & $4.353 \mathrm{c}$ & 11.50 & $87 \mathrm{~b}$ & 5.14 \\
\hline 13 MPA 01 x SJC 5886 & $3.798 \mathrm{~b}$ & 21.08 & 93 a & 4.94 \\
\hline 14 SJC 5886 x MPA 01 & $4.884 \mathrm{c}$ & 55.70 & $90 \mathrm{a}$ & 1.83 \\
\hline 15 Pixurum 05 x SCS 155 Catarina & $3.036 \mathrm{a}$ & -26.04 & $92 \mathrm{a}$ & 8.53 \\
\hline 16 SCS 155 Catarina x Pixurum 05 & $4.111 \mathrm{c}$ & 0.15 & $87 \mathrm{~b}$ & 2.06 \\
\hline 17 Pixurum 05 x AS1565 & $4.640 \mathrm{c}$ & -0.23 & 90 a & 9.48 \\
\hline 18 AS 1565 x Pixurum 05 & $4.712 \mathrm{c}$ & 1.32 & $88 \mathrm{~b}$ & 7.95 \\
\hline 19 Pixurum 05 x SJC 5886 & $4.039 \mathrm{c}$ & 3.98 & $89 \mathrm{~b}$ & 1.00 \\
\hline 20 SJC 5886 x Pixurum 05 & $2.792 \mathrm{a}$ & -28.13 & 95 a & 8.13 \\
\hline 21 Pixurum 05 x BRS 4150 & $3.778 \mathrm{~b}$ & -17.93 & $87 \mathrm{~b}$ & 0.58 \\
\hline 22 BRS 4150 x Pixurum 05 & $3.666 \mathrm{~b}$ & -20.36 & $92 \mathrm{a}$ & 6.38 \\
\hline 23 Fundacep 35 x SCS 154 Fortuna & $4.591 \mathrm{c}$ & 2.86 & 93 a & 5.08 \\
\hline 24 SCS 154 Fortuna x Fundacep 35 & $4.932 \mathrm{c}$ & 10.50 & $90 \mathrm{a}$ & 1.13 \\
\hline 25 Fundacep 35 x AS 1565 & $3.713 \mathrm{~b}$ & -20.39 & $89 \mathrm{~b}$ & 4.27 \\
\hline 26 AS 1565 x Fundacep 35 & $4.666 \mathrm{c}$ & 0.04 & $79 \mathrm{c}$ & -7.22 \\
\hline 27 AS 1565 x SCS 154 Fortuna & $3.686 \mathrm{~b}$ & -18.95 & $91 \mathrm{a}$ & 10.81 \\
\hline 28 SCS 154 Fortuna x AS 1565 & $4.487 \mathrm{c}$ & -1.34 & $89 \mathrm{~b}$ & 7.76 \\
\hline
\end{tabular}

Measures followed by the same letter in the column do not differ inwardly by the Scott \& Knott test, at $5 \%$. 
Singh's method (1981) was used to evaluate the relative importance of the six physiological variables in the genetic divergence. The results of vigor by the accelerated aging presented a higher contribution $(66,66 \%)$, followed by germination $(18,41 \%)$ and the germination speed $(10,04 \%)$ (Figure 1).

Relative Importance (Singh, 1981)

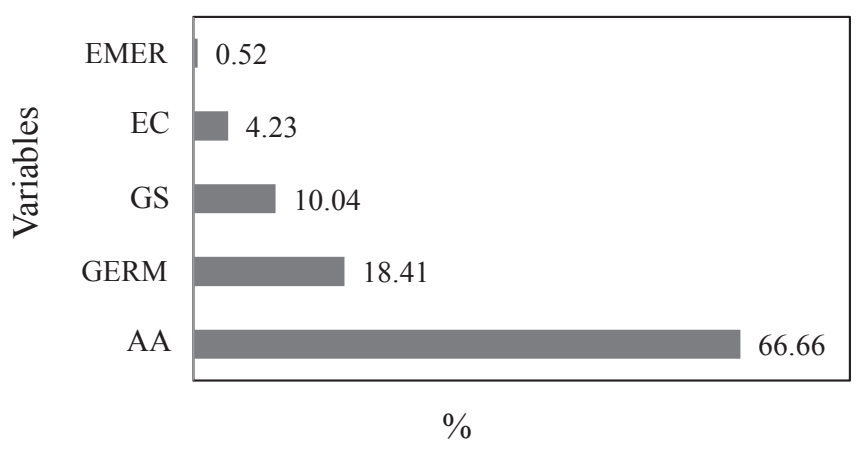

Figure 1. Relevant contribution of variables for the diversity. Singh (1981) criteria based on $\mathrm{D}^{2}$ of Mahalanobis. EMER - Field emergence; EC Electrical conductivity; GS - Germination speed index; GERM - Germination; AA - vigor by accelerated aging.

Thus, it is possible to state there is a need to perform physiological quality tests in the seeds in order to establish the genetic potential for germination and vigor. In the present study, the accelerated aging test was the best option to discriminate the difference among genotypes. Moreover, the divergence and genetic relations studies regarding physiological quality support the selection strategies, aiming at the physiological quality of seeds (Cardoso et al., 2009).

The grouping analysis of 28 treatments, based on the genetic differences and considering six characteristics related to the seeds quality, enabled the creation of 11 groups (Table 4).

By analyzing the variables contribution for the genetic diversity, it was possible to note that group VI genotypes had more physiological response than the others, that is, germination (96\%), GS (3,61 days), electrical conductivity $\left(4,11 \mu \mathrm{S} \cdot \mathrm{cm}^{-1} \cdot \mathrm{g}^{-1}\right)$, accelerated aging $(86,1 \%)$ and field emergence $(91,8 \%)$, and did not present relevant variations among them regarding the germination on the accelerated aging test (most contributing variable for diversity). Group VI presented similarities in the crossbreeds' composition, which confirms the statement of Santos et al. (2012), who said genotypes from the same group are genetically similar and their combinations may cause inferior variability when compared with the other groups. Yet, the differences observed among the groups were not big, indicating, therefore, other means to analyze the results (Table 5).
Table 4. Composition of groupings established by Singh's Method applied to the matrix of genera distances by Mahalanobis $\left(\mathrm{D}^{2}\right)$ among 28 corn genotypes.

\begin{tabular}{ccl}
\hline Group & № of Genotypes & \multicolumn{1}{c}{ Genotypes* } \\
\hline I & 5 & 524272211 \\
II & 4 & 1417188 \\
III & 4 & 16212825 \\
IV & 4 & 14212 \\
V & 2 & 626 \\
VI & 3 & 91320 \\
VII & 2 & 710 \\
VII & 1 & 15 \\
IX & 1 & 3 \\
X & 1 & 19 \\
XI & 1 & 23 \\
\hline
\end{tabular}

*Indication of the 28 genotypes is found in Table 1.

Table 5. Germination speed (GS), germination percentage (G), accelerated aging (AA), field emergence (EM) and electrical conductivity (EC) of the groupings established by Singh's method.

\begin{tabular}{|c|c|c|c|c|c|}
\hline Grouping & $\begin{array}{c}\text { GS } \\
\text { days }\end{array}$ & $\begin{array}{l}\mathrm{G} \\
\%\end{array}$ & $\begin{array}{c}\text { AA } \\
\%\end{array}$ & $\begin{array}{c}\text { EM } \\
\%\end{array}$ & $\begin{array}{c}\text { EC } \\
\mu \mathrm{S} \cdot \mathrm{cm}^{-1} \cdot \mathrm{g}^{-1}\end{array}$ \\
\hline 1 & 4.09 & 95 & 91 & 92 & 4.22 \\
\hline 2 & 3.60 & 96 & 89 & 88 & 4.69 \\
\hline 3 & 4.11 & 94 & 88 & 89.7 & 3.94 \\
\hline 4 & 3.61 & 96 & 86.1 & 91.8 & 4.11 \\
\hline 5 & 3.93 & 98 & 79 & 91.5 & 4.69 \\
\hline 6 & 3.90 & 91 & 94 & 90 & 3.04 \\
\hline 7 & 3.67 & 92 & 91 & 90 & 3.08 \\
\hline 8 & 3.66 & 98 & 92 & 94 & 2.97 \\
\hline 9 & 4.07 & 90 & 85 & 94 & 3.72 \\
\hline 10 & 4.12 & 99 & 89 & 90 & 4.04 \\
\hline 11 & 4.37 & 90 & 93 & 82 & 4.50 \\
\hline
\end{tabular}

The first two canonical variables enabled the explanation of $86,9 \%$ of the variation (Figure 2). Five groups were created based on the canonical variables. The relative importance of each characteristic in the canonic variables (Figure 1) enables the classification of genotypes in accordance with their performance on accelerated aging, germination, GS, electrical conductivity and field emergence tests.

Group I was composed by genotypes 9, 11, 13, 20 and 23, which presented the following medians: accelerated aging 94\%, germination 92\%, GS 4,00 days, electrical conductivity $3,69 \mu \mathrm{S} \cdot \mathrm{cm}^{-1} \cdot \mathrm{g}^{-1}$, and field emergence $88 \%$. Group II is composed by 19 genotypes, whose means were: accelerated aging $89 \%$, germination 95\%, GS 3,9 days, electrical conductivity $4,04 \mu \mathrm{S} . \mathrm{cm}^{-1} \cdot \mathrm{g}^{-1}$ and field 
emergence 91\%. Genotype Pixurum 05 integrates Group III with the following means: accelerated aging $85 \%$, germination $98 \%$, GS 3,53 days, electrical conductivity $4,61 \mu \mathrm{S} . \mathrm{cm}^{-1} \cdot \mathrm{g}^{-1}$ and field emergence $88 \%$. Group IV is composed by the genotype SCS 155 Catarina, which presented the following means: accelerated aging $85 \%$, germination $90 \%$, GS 4,07 days, electrical conductivity $3,72 \mu \mathrm{S} . \mathrm{cm}^{-1} \cdot \mathrm{g}^{-1}$ and field emergence $94 \%$. Group $\mathrm{V}$ is composed by the parental AS 1565 and crossbreed 26, presenting the following means: accelerated aging $79 \%$, germination $98 \%$, GS 3,93 days, electrical conductivity $4,69 \mu \mathrm{S} . \mathrm{cm}^{-1} \cdot \mathrm{g}^{-1}$ and field emergence $91,5 \%$.

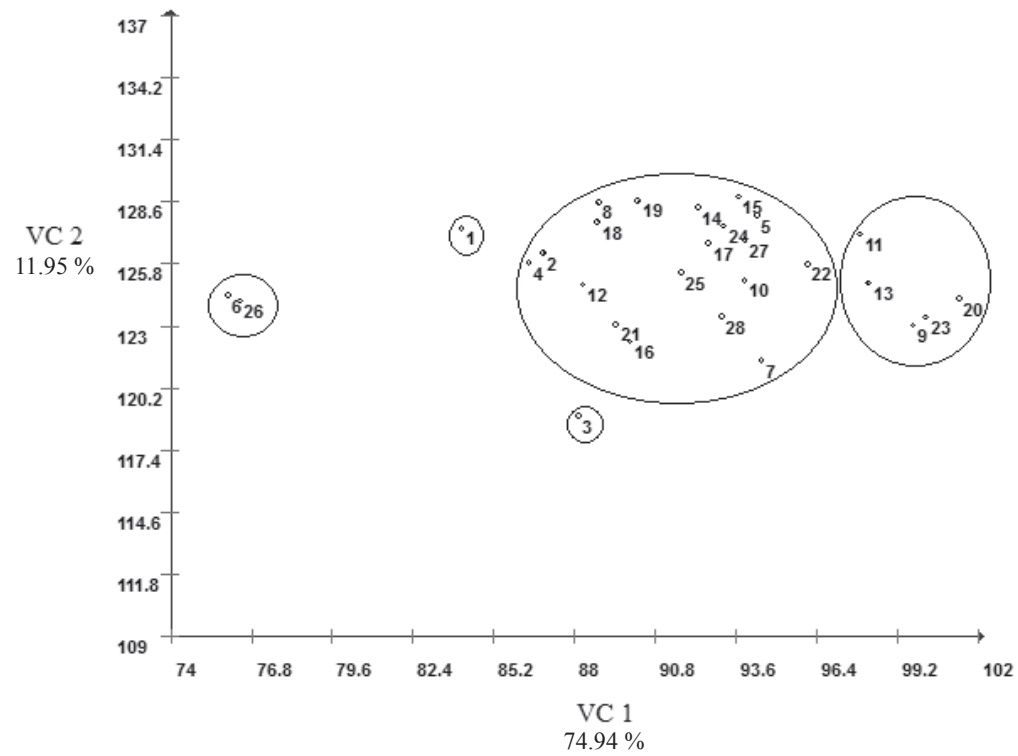

Figure 2. Scatterplot of corn genotypes in relation with the representative axis of canonical variables (VC1 e VC2) regarding six variables studies in corn (Zea mays L.) based on the physiological characteristics of corn seeds. The numbers corresponding to the genotypes are described in Table 1.

Based on such results, the use of canonical variables was the best option to discriminate the genotypes regarding the physiological quality. Also, Group 1 genotypes presented the best performance. The 19 genotypes of Group II, along with Group III, presented intermediate characteristics. Groups IV and $\mathrm{V}$ presented low performance on the variables considered. The canonical variables were important to show the genetic difference of the genotypes. The genotypes belonging to Group I $(9,11,13,20,23)$ are indicated as the best crossbreeds for the production of great physiological quality seeds.

\section{Conclusions}

The crossbreed seeds are viable and vigorous and present heterosis when compared to their parentals. The existence of the equivalent effect shows there must be attention at the moment of choosing the parental in order to obtain better physiological quality seeds.

The accelerated aging test proved to be the best option to specify the genetic diversity $(66,66 \%)$, being considered important to discriminate the genotypic potential.
The canonical variables were efficient for grouping genotypes with similar physiological characteristics. Genotypes 9 (MPA 01 x Pixurum 05), 11 (MPA 01 x AS 1565), 13 (MPA 01 x SJC 5886), 20 (SJC 5886 x Pixurum 05 ) and 23 (Fundacep 35 x SCS 154 Fortuna) produced seeds with the best physiological quality.

\section{Acknowledgment}

We are grateful to Cooperativa Oestebio and Fundação de Amparo à Pesquisa e Inovação do Estado de Santa Catarina FAPESC, Grant Contract n-10.043/2012-9, process 1877/2012, CNPQ (Centro Nacional de Desenvolvimento Cientifico e Tecnológico) for the financial support for corresponding author.

\section{References}

ÁVILA, M.B.; ALBRECHT, L.P. Isoflavonas e a qualidade das sementes de soja. Informativo ABRATES, v.20, n.1,2, p.15-29, 2010. http://www.abrates. org.br/portal/ images/stories/informativos/v20n12/artigo02.pdf 
BITTENCOURT, S.R.M.; GRZYBOWSKI, C.R.S.; PANOBIANCO, M.; VIEIRA, R.D. Metodologia alternativa para condução do teste de envelhecimento acelerado em sementes de milho. Ciência Rural, v.42, n.8, p.1360-1365, 2012. http://www.scielo.br/scielo.php?pid=S0103$84782012000800005 \&$ script $=$ sci_arttext\&tlng $=$ pt

BRASIL. Ministério da Agricultura, Pecuária e Abastecimento. Regras para análise de sementes. Ministério da Agricultura, Pecuária e Abastecimento. Secretaria de Defesa Agropecuária. Brasília: MAPA, 2009. 395p. http://www. bs.cca.ufsc.br/publicacoes/regras\%20analise $\% 20$ sementes.pdf

CARDOSO, D.L.; SILVA, R.F.; PEREIRA. M.G.; VIANA, A.P.; ARAÚJO, E.F. Diversidade genética e parâmetros genéticos relacionados à qualidade fisiológica de sementes em germoplasma de mamoeiro. Revista Ceres, v.56, n.5, p.572-579, 2009. http://www.ceres.ufv.br/ceres/revistas/V56N005P04108.pdf

COELHO, C.M.M.; MOTA, M.R.; SOUZA, C.A.; MIQUELLUTI, D.J. Potencial fisiológico em sementes de cultivares de feijão crioulo (Phaseolus vulgaris L.). Revista Brasileira de Sementes, v.32, n.3, p.97-105, 2010. http:// www.scielo.br/pdf/rbs/v32n3/v32n3a11.pdf

CRUZ, C.D. Programa Genes: Biometria. Viçosa: UFV, 2006, 382p.

CRUZ, C.D.; REGAZZI, A.J.; CARNEIRO, P.C.S. Modelos biométricos aplicados ao melhoramento genético. v.1, 3.ed., Viçosa: UFV, 2004. 480p.

EDMOND, J.B.; DRAPALA, W.S. The effects of temperature, sand and acetone on germination of okra seed. Proceedings of the American Society for Horticultural Science, v.71, p.428-434, 1958.

GOMES, M.S.; VON PINHO, E.V.R.; VON PINHO, R.G.; VIEIRA, M.G.G.C. Efeito da heterosis na qualidade fisiológica de sementes de milho. Revista Brasileira de Sementes, v.22, n.1, p.7-17, 2000. http://www.abrates. org.br/revista/artigos/2000/v22n1/artigo02.pdf

GONDIM, T.C.O.; ROCHA, V.S.R.; SANTOS, M.M.; MIRANDA, G.V. Avaliação da qualidade fisiológica de sementes de milho-crioulo sob estresse causado por baixo nível de nitrogênio. Revista Ceres, v.53 p.413-417, 2006. http://www.ceres.ufv.br/ceres/revistas/V53N307P05906.pdf

MARCOS-FILHO, J. Fisiologia de sementes de plantas cultivadas. Piracicaba: FEALQ, 2005. 495p.

MARCOS-FILHO, J. Teste de envelhecimento acelerado. In: KRZYZANOWSKI, F.C.; VIEIRA, R.D.; FRANÇA-NETO, J.B. (Ed.). Vigor de sementes: conceitos e testes. Londrina: ABRATES, 1999. cap.3, p.1-24.
MERTZ, L.M.; HENNING, F.A.; CRUZ, H.L.; MENEGHELLO, G.E.; FERRARI, C.S.; ZIMMER, P.D. Diferenças estruturais entre tegumentos de sementes de soja com permeabilidade contrastante. Revista Brasileira de Sementes, v.31, n.1, p.23-29, 2009. www.scielo.br/pdf/rbs/v31n1/a03v31n1.pdf

MIRANDA, G.V.; CANIATO, F.F.; FIDELIS, R.R.; ARAUJO, E.F.; SOUZA, L.V.; DONÁ, A.A. Qualidade fisiológica de sementes de populações de milho crioulo na zona da mata de Minas Gerais. Revista Ceres, v.50, p.337-345, 2003. http://www.ceres.ufv.br/ceres/revistas/V50N289P21803.pdf

MOTERLE, L.M.; BRACCINI, A.L.; SCAPIM, C.A.; PINTO, R.J.B.; GONÇALVES, L.S.A.; AMARAL JUNIOR, A.T.; SILVA, T.R.C. Combining ability of tropical maize lines for seed quality and agronomic traits. Genetics and Molecular Research, v.10, n.3, p.2268-2278, 2011. http://www. geneticsmr.com/articles/1285

NAKAGAWA, J. Testes de vigor baseados na avaliação das plântulas. In: VIEIRA, R.D.; CARVALHO, N.M. (Ed.). Testes de vigor em sementes. Jaboticabal: FUNEP, 1994. p.48-85.

PEREIRA, A.F.; MELO, P.G.S.; OLIVEIRA, J.P.; ASSUNÇÃO, A.; BUENO, L.G. Qualidade fisiológica de sementes e desempenho agronômico de milho doce. Pesquisa Agropecuária Tropical, v.38, n.4, p.249-261, 2008. http://www.revistas.ufg.br/index.php/pat/article/view/5077/4230

PRETE, C.E.C.; GUERRA, E.P. Qualidade fisiológica de sementes. In DESTRO, D.; MONTALVAN, R. (Eds.) Melhoramento genético de plantas. Londrina: UEL, 1999. p.659-674.

REIS, L.S.; PEREIRA, M.G.; SILVA, R.F.; MEIRELES, R.C. Efeito da heterose na qualidade de sementes de milho doce. Revista Brasileira de Sementes, v.33, n.2, p.310-315, 2011. http://www.scielo.br/pdf/rbs/v33n2/13.pdf

SANTOS, E.R.; BARROS, H.B.; CAPONE, A.; MELO, A.V.; CELLA, A.J.; SANTOS, W.R. Divergência genética entre genótipos de soja com base na qualidade de sementes. Revista Brasileira de Ciências Agrárias, v.7, n.2, p.247-254, 2012. http://agraria.pro.br/sistema/index.php?journal=agraria\&page $=$ article\&op=view\&path[] $=$ v7i2a1560\&path[]=1111

SINGH, D. The relative importance of characters affecting genetic divergence. The Indian Journal of Genetic and Plant Breeding, v.41, n.2, p.237-245, 1981. http://www.indianjournals.com/ijor. aspx? target $=$ ijor:ijgpb\&volume $=41 \&$ issue $=2 \&$ article $=010$

VIEIRA, R.D.; CARVALHO, N.M. Testes de vigor em sementes. Jaboticabal: FUNEP, 1994. 164p. 